\title{
Meanings and Perspectives of Reconciliation in the Australian Socio-political Context
}

\author{
Nina Burridge, University of Technology, Australia
}

\begin{abstract}
The policy of national reconciliation between Indigenous and non Indigenous peoples has been on the social and political agenda for decades, yet progress on this issue of Australian's 'unfinished business', seems to have stalled in the last few years. This paper seeks to map the various interpretations and meanings of 'reconciliation' in the Australian sociopolitical context, from the creation of the Council of Aboriginal Reconciliation in 1991, to the controversies emerging from the 'cultural wars' history debates of the last few years. It provides an framework for the various discourses of Reconciliation, by exploring and analysing the accrued meanings to such terms such as 'genuine' or 'true' reconciliation 'symbolic' reconciliation and 'practical Reconciliation' a term used extensively under the Prime Ministership of John Howard. In the current political context in Australia is reconciliation no more than a normative discourse - a symbolic gesture by mainstream Australia to maintain the status quo and divert our eyes from the more searching questions of the 'unfinished business' of 'substantive' reconciliation such as the issue of a treaty and just compensations for past injustices for Aboriginal people. This paper suggests that the journey towards reconciliation between black and white Australians is convoluted and complex. It is mired with political and social agendas which are inextricably linked with the national consciousness, with Australia's sense of self, the various views and interpretations of its history, and its multiple national identities. In reality, given the lack of national will to address the substantive issues of reconciliation, the journey still has many a path to tread.
\end{abstract}

Keywords: Cultural Diversity, Reconciliation, Indigenous, Black White Relations

\section{Introduction}

$\mathrm{I}$ N THE BROADER historical sense, and in its widest interpretation, reconciliation is a contemporary name for the struggle for justice for $\mathrm{Ab}$ original people in Australia which stretches back to the early $19^{\text {th }}$ Century. It embodies all the efforts and struggles of Indigenous and non Indigenous peoples for coexistence since Europeans first landed and established settlements on Indigenous country.

In the official context, Aboriginal reconciliation is a policy endorsed by Federal and State Parliaments, bipartisan in nature, following on from previous policies such as Assimilation, Integration, and Self-Determination. It was enacted by a unanimous vote of the Australian Federal Parliament in September 1991. It may also be seen as an attempt at a populist movement emerging from the work of the Council for Aboriginal reconciliation (CAR), formed in 1991 to support the new policy. Populist in the sense that the work the Council was designed to do was to reach the everyday Australian citizen to educate them about the meaning of reconciliation. However, since 1991 meanings accrued to reconciliation have come been contested and debated.

\section{A Framework for Defining Reconciliation}

The dynamics of the discourse of reconciliation illustrate the multitude of meanings and interpretations accrued to the term that are often driven by a variety of socio-political agendas. These representations and agendas vary according to the prevailing ideology as well as individual belief. For example, many nonAboriginal people prefer a non-political approach to reconciliation while for many Aboriginal people you cannot dissect the political and ideological from the such a policy. All these views are valid, some might say essential, despite the superficiality of particular elements, to the whole discursive complexities and representations of the issues and events of the reconciliation movement in Australia.

In this paper, terms such as 'practical' reconciliation; reconciliation rhetoric; 'symbolic' reconciliation; 'genuine' reconciliation; 'true' reconciliation; 'substantive' reconciliation; 'soft' reconciliation and 'hard' reconciliation will be used to assist the deconstruction process of finding meanings of reconciliation within the Australian community.

The overarching message of reconciliation is overwhelmingly positive and idealistic, as can be seen in the Council for Aboriginal Reconciliation's vision which stated "A united Australia which respects this land of ours, values the Aboriginal and Torres Strait Islander heritage and provides justice and equity for all" (CAR, 1992, p. 1). In the context of a nation not fully at ease with its pasts, this focus on nation building and the search for better relations between two very different cultures, begs many questions. A pivotal point of the discussion is the extent to which policy and leadership are used to 
shape the collective consciousness on reconciliation or whether such policy is shaped by populist rhetoric.

Other questions which arise relate to the extent of support for the 'hard/substantive' issues of reconciliation such as a 'treaty' and just compensation for past injustices as opposed to the 'soft', more symbolic (often rhetorical) type of reconciliation preferred by some non Indigenous leaders in the community. Increasingly the Australian Federal government has given credence to 'practical' reconciliation as a viable alternative.

In order to provide a framework for analysis, a diagrammatic representation of the reconciliation spectrum would present as follows:

\begin{tabular}{lll} 
LEFT & CENTRE & \multicolumn{1}{c}{ RIGHT } \\
Hard & Soft & Assimilationist \\
$\begin{array}{l}\text { Substantive } \\
\text { 'Genuine' or 'true' }\end{array}$ & Symbolic - Rhetorical & Normative - Practical - \\
- 'treaty'/sovereignty & • ceremonies & - standard health \\
• compensation & • marches & - housing \\
• land/sea rights & • gatherings, celebrations & • education \\
• first nations people & • aspirational & • all one nation
\end{tabular}

Fig 1: Reconciliation Typologies

'Hard', 'genuine', 'true', or 'substantive' reconciliation refers to the demands by Indigenous leaders for recognition of the unique rights Indigenous people possess that have to do with 'native title', customary laws, the right to just compensation for past acts of dispossession, and a 'treaty' with nonIndigenous peoples.

'Symbolic' reconciliation is the most popular amongst mainstream Australians. The symbols of reconciliation are seen as 'soft' and non adversarial: they are at times superficial and tokenistic.

The rhetoric of reconciliation refers to all the political speak of the policies, the hyperbole and the false aspirations, (often uttered by politicians), which are not backed up by the actions/deeds of reconciliation.

At the more conservative end of the reconciliation spectrum is found Prime Minister Howard's 'practical' reconciliation - referring to the programs and strategies designed to correct the level of social and economic disadvantage in health, housing and education faced by Indigenous communities throughout the nation. To the more conservative elements in mainstream Australia, reconciliation is about equality and assimilation rather than Aboriginal peoples possessing distinct political and cultural rights. In this mode, reconciliation merely affirms the status quo - it becomes a normative discourse perpetuating mainstream cultural values to which all Australians should have a right to aspire.

It is argued that 'Hard' or 'substantive' reconciliation involves the acceptance of a treaty, a bill of rights, just compensation and a social justice package which clearly addresses Indigenous disadvantage. 'Soft' reconciliation encompasses the 'feelgood' symbolic elements such as the public events and ceremonies of reconciliation.

'Soft', 'symbolic' reconciliation is seen by many, as necessary as it is more palatable for mainstream Australia to embrace. In the final analysis, however, it is insufficient. At worst, it is a very cheap form of reconciliation - a few speeches on key days — but there is no depth of understanding of the real issues. At best, it extends to the symbolic representations of reconciliation - attendance at gatherings and ceremonies - which are at times superficial, at times tokenistic, but taken as incremental steps on the long road to attitudinal change, can actually create a critical cultural shift in thinking. Symbolic representations are important in so far as they work to bring people together and provide building blocks for the future through a slow advancement of the 'hard' or 'substantive' issues of reconciliation.

Within the community, for example, symbolic victories by Indigenous athletes or Indigenous artists can help to publicise the cause of reconciliation in a lateral way - by heightening awareness of Indigenous people and their achievements. When Cathy Freeman lit the Olympic flame and won the 400 metres final at the Sydney Olympic Games in September 2000, it was a triumph for reconciliation. Anne Summers claimed in the Sydney Morning Herald that the choice of Cathy Freeman to light the Olympic cauldron "redefined Australia to the rest of the world" (Summers, 2000, p. 12). Such hyperbole is often evident in the reporting of what can be called 'symbolic' representations of reconciliation. The question remains however, how long does the euphoria of success last and will attitudes to the 'substantive' issues of reconciliation be enhanced by such 
symbolic displays of Aboriginal athletes and Aboriginal culture as occurred in the opening and closing ceremonies?

The varying interpretations of meanings of reconciliation were evident in the Sydney Bridge Walk 2000 when some 250,000 walkers crossed the Harbour Bridge. Again, it was hailed as a great triumph for reconciliation. Capitalising on the huge crowd, many Aboriginal leaders saw the walk as a mandate for a treaty. Interestingly, the same triumphal support was not afforded to the call for a treaty by the mainstream media, as a subsequent editorial in The Australian stated, "ATSIC Chairman Geoff Clarke used the Sydney Harbour walk to claim a mandate for a treaty. He was wrong. People walked for reconciliation" (The Australian, 8 December 2000, p. 12).

Herein lies the deep paradox of reconciliation. To make it palatable it must be 'soft' -'warm and fuzzy', symbolic - but to make it real and acceptable to Indigenous Australians it must have depth. To many, if reconciliation is not about a treaty- with all of its concomitant repercussions (compensation, social justice, a charter of rights, land rights) - then it is just empty rhetoric accompanied by a few symbolic gestures. For 'true' reconciliation to occur the 'hard' or 'substantive' issues need to be discussed in the broader mainstream community.

In short, was the walk across the Harbour Bridge in Sydney and the waving of Aboriginal flags when Cathy Freeman won Olympic gold in September 2000 , described as "400 metres of reconciliation" (Beazley, 2000, cited in Rintoul , 2000, p. 1) the limit of what non Indigenous people would do for reconciliation? Is this support for the 'soft' issues of reconciliation merely another version of Prime Minister Howard's 'practical' reconciliation — ie a process which reflects the wishes of mainstream Australia? In other words, is the only acceptable form of reconciliation that which is defined by the dominant culture? Consequently, is the reconciliation movement only fulfilling a government-initiated agenda to channel sentiment into 'soft', symbolic events and then claim that reconciliation is being achieved? These, amongst others, are some of the crucial questions needing further analysis in the discourse of meanings of reconciliation.

\section{Community Perceptions}

During its ten year existence, the Council for Aboriginal Reconciliation conducted social research into community attitudes and awareness of reconciliation.

It was apparent that while the higher echelons of the Federal government at the time welcomed the real attempts at bridging the divide between black and white Australia - at least in the symbolic sense, there was some ambivalence to reconciliation amongst Australians. In the words of a 1996 report prepared for the Council of Aboriginal Reconciliation by Sweeney and Associates, Unfinished Business, "The concept of reconciliation throws out a challenge to the wider community. It evokes both hopes and fears" (p. 3). Hope in that "Spontaneous reactions to reconciliation ... generally result in a positive interpretation, encapsulated in words like: recognition, acknowledgment (prior occupation, loss); co-existence ; harmony; unity (not perpetuating 'them and us'); acceptance: sharing (of both cultures); consultation (between all parties) (p. 3).

Fears, because "For some, support for reconciliation may not always be based on goodwill but fears about a society becoming degraded by divisions and hatred" (Sweeney \& Associates, 1996, p. 3). This idea of fear can work as a barrier to reconciliation. Indeed the report lists fear, apathy and ignorance as the barriers to reconciliation (p. 4).

Apathy and indifference is a prevailing condition in Australian attitudes to politics and this is reflected in this comment. "I live in a suburban area, there isn't any need for reconciliation because everyone minds their own business" (CAR, undated, p. 53). According to the evidence in another extensive poll conducted for CAR (Newspoll, 2000) there still existed a gap between what constitutes (in theoretical terms) 'true' or 'substantive' reconciliation in the guise of a treaty, an apology and just compensation for those active in the push for reconciliation and reconciliation as defined by mainstream Australia which largely focuses on symbolic representations .

A further study using qualitative data conducted by Irving, Saulwick and Associates in 2000, while acknowledging that different groups in the community varied in their support for reconciliation, reinforced the view that most mainstream Australians were largely ignorant of, or apathetic towards reconciliation:

The abstract idea of reconciliation is widely supported. However once people look at the subject in depth their reaction is a mixture of hope, hostility, confusion and boredom. (Irving Saulwick \& Associates, 2000, p. 18).

There has been little research into Australians' attitude to reconciliation since 2001 and the end of the Council for Aboriginal Reconciliation.

It could be argued that the very elements of fear, apathy and ignorance noted in 1996, were still part of the national psyche some ten years later when, despite efforts from some quarters, reconciliation and Indigenous issues do not feature prominently in the policy documents of both major political parties in Australia. 


\section{Practical Reconciliation}

The tide of Australian Federal politics in relation to Indigenous policy changed in 1996 after the election of a conservative Federal government in March of that year. The difference between what constituted 'true' or 'substantive' and 'practical' reconciliation became increasingly apparent.

This shift in policy on Indigenous issues was evidenced by the funding cuts to the Aboriginal and Torres Straight Islander Commission (ATSIC) (Brough, SMH, 1996, p. 1) and the impact of the election to Federal Parliament of Pauline Hanson and the formation of her One Nation party. The arrival of Hansonism changed the flavour of politics in Australia by adding a new measure of conservatism. There now existed an extreme right-wing faction within the Australian political system which by 1998 was able to harness $8-10 \%$ of the vote nationally and more than $20 \%$ in some electorates $(S M H, 16$ June, 1998).

The white backlash on Indigenous issues manifest itself in the negotiations in the 'native title debate' which had provided a back drop to the discourse on reconciliation since 1992 when the High Court voted to allow the existence of Native Title on unalienated Australian soil. The debate continued as the High Court extended native title rights in the Wik case in December 1996, to give Aboriginal people the right to coexistence on pastoral leases. The "ten-point Wik plan' the Prime Minister popularised to nullify the impact of the Wik decision was a hotly contested issue throughout 1997 and 1998.

This is the context in which the changing meanings of reconciliation must be analysed at the beginning of the new century. Increasingly, the agenda on reconciliation - at least as far as the Federal Government was concerned - was a different model to that ascribed to by Indigenous communities and their non Aboriginal supporters.

Prime Minister John Howard's call for "practical" reconciliation had been a feature of many of his public addresses including the National Reconciliation Convention- a gathering of many Indigenous and non -Indigenous Australians held in 1997. It was at this convention that a significant number of delegates turned their backs to the Prime Minister as a protest at his refusal to say 'sorry' for past acts of injustice towards Indigenous peoples.

In the lead-up to Corroboree 2000 the celebrations designed to coincide with the centenary of Federation there was a massive nation wide focus on reconciliation, the Prime Minister wrote in the Sydney Morning Herald:

National reconciliation calls for more than recognition of the damaging impact on people's lives of the mistaken practices of the past. It also calls for a clear focus on the future. It calls for practical policy making that effectively addresses current indigenous disadvantage, particularly in areas such as employment, health, education and housing (Howard, 2000, SMH Features, p. 1).

In answer to the notion of 'practical' reconciliation Mick Dodson responded in his Corroboree 2000 speech by declaring:

Don't be distracted by notions of practical reconciliation, because they mean practically nothing. Now, although issues of health, housing and education of indigenous Australians are of course of key concern to us as a nation, they are not issues that are at the very heart or the very soul of reconciliation. But they are, to put it quite simply and plainly, the entitlements every Australian should enjoy... reconciliation is about deeper things, to do with nation, soul and spirit, reconciliation is about the blood and flesh of the lives we must lead together, and not the nuts and bolts of the entitlements as citizens we should enjoy (Dodson, M., 27 May 2000).

In this passionate speech Mick Dodson hit at the very core of the meaning of reconciliation for Indigenous people. First and foremost, reconciliation must be about recognition and identity and the efforts which need to be made for black and white to live side by side with mutual respect. Hence, 'true' reconciliation requires more than just economic programs and entitlements to spending because of the disadvantaged position of Aboriginal people. These entitlements are a human right, not a privilege of being an Australian citizen. 'True' reconciliation encompasses all facets of Aboriginal and non established Aboriginal relationships - it is defined by nationhood, by human rights and by respect for each other as citizens with equal rights and opportunities.

\section{Reconciliation as a Normative - Assimilationist Policy}

In contrast some non Aboriginal Australians see these sovereign rights as threatening to mainstream Australia's sense of nationhood.

It is a theme taken up by Anthony Moran (1998) in an article titled "Aboriginal Reconciliation: Transformations in Settler Nationalism".

He notes that current trends towards globalisation have undermined national identities and that this has compounded the anxieties in Australians' own formulations of their national identities, particularly in relation to how Indigenous peoples feature in those identities. According to Moran, this changing landscape has caused great uncertainty. Indigenous de- 
mands of Reconciliation - in other words 'true' or 'substantive' Reconciliation call into question Australia's heroic past. The legitimacy of the Australian nation as a good and just society has been called into question by the historical record and by reports such as Bringing Them Home (1997). This 500 page report outlined the gross injustices committed against Indigenous peoples in the past when they were forcibly removed from their families via government legislation. Those removed came to be known as the 'stolen generations'.

According to the progressive historian, Henry Reynolds (1999, p. 117), the real problem with reconciliation is that in the hands of conservatives it can indeed have an assimilationist agenda. He sees assimilation as one strand of the reconciliation movement — that desire to blend races together harmoniously without recognition of distinct rights for Aboriginal peoples. In this sense reconciliation is no more than a normative movement acting to reinforce old style assimilationist tendencies.

An example of this assimilationist view is provided by one member of the Right, the Hon Peter Howson Minister for Aboriginal Affairs in the early 1970s. In his report to the Senate's Legal and Constitutional Committee's Inquiry into progress towards reconciliation initiated by the Senate in 2002 he states:

The question that surely has to be asked is how is it possible to have reconciliation when advocacy by Aboriginal leaders (and, regrettably, by a few other well-intentioned people) promotes the establishment of a more separate existence, when the great majority of Australians clearly want to live in one country and under one law, and when in reality the great majority of Aborigines themselves are living with non-indigenous partners and in urban centers of mixed populations? The essence of reconciliation is surely to establish, and build upon, economic and societal structures that will encourage living together in reasonable harmony, not to try constantly to establish arrangements that would provide encouragement to living apart (Howson, 2002, p. 3).

The intrinsic links between the 'stolen generations'; the 'sorry debate'; the nature of our history and our search for an inclusive Australian identity seem to converge in the reconciliation discourse. The very mixed community reaction to expressing sorry for past in justices in the 'Sorry Day' commemorations during Reconciliation Week in 1998, prompting organisers to call it the 'Journey of Healing' in the following years, is an indication of the uncertainty and the anxieties surrounding the debate on what reconciliation means to us as individuals, and in the collective sense as a nation of diverse peoples.

The need for the 'feel-good' nature of reconciliation is one of the recurring themes which emerges in all reconciliation research. As Pratt, Elder and Ellis (2001) note, "The 'feel-good' nature of the rhetoric of the reconciliation 'journey' means that reconciliation is often the most comfortable way non Indigenous people conceptualise their relationship to Indigenous peoples"(p. 146). Yet this often leads to the silencing of Indigenous voices who sit outside the mainstream of 'soft' reconciliation.

Therefore Howson (2002) and others of the Right (Johns and Brunton,1999; Partington, 1998; Windschuttle, K 2002).) seem to adhere to the notion of reconciliation at the very least as a normative if not assimilationist political project; one designed to maintain the status quo or even further to deny the unique rights of first nations peoples to Australia's Indigenous population. In this discourse, Indigenous people are expected to reconcile themselves to their dispossession because in reality, the civic, legal and political system which dispossessed them of their culture and lands was far superior to their traditional ways- as this quote illustrates. According to Johns and Brunton (1999):

A large element of reconciliation is the recognition on the part of Aboriginal people that their land was colonised two hundred years ago by a people who fortunately did not attempt the genocide of the original inhabitants and who have brought with them the most respected means of governance devised, a most bountiful economy, the most brilliant intellectual traditions and an openness and tolerance unknown in Aboriginal culture (p. 10).

\section{1 and Beyond: Concluding Comments}

The term of the Council for Aboriginal Reconciliation came to an end in January 2001. It was replaced by a smaller body called Reconciliation Australia. Since then the 'unfinished business' of reconciliation has remained unfinished. Indeed some might say that is has regressed further into the recesses of the national psyche-overtaken by other concerns resulting from post 9/11 fears of terrorism and Australia's well documented attempts at border control through a very punitive refugee policy which mandatory detains anyone one seeking asylum on its shores. Australians on the one hand, have become manifestly inward looking and insular, yet on the surface they boast one of the most successful experiments into multiculturalism in the world - another interesting paradox in the history of the Australian nation state - but that is a story for another time. 
This paper has presented various interpretations and meanings in the political and social project of reconciliation in the context of contemporary Australia. Reconciliation is such a malleable term that it has been used and misused by individuals and institutions to advance any number of agendas. The rhetoric of reconciliation is ever present in speeches and ceremonies. The word reconciliation adorns book titles and is written into the précis of descriptions of art exhibitions, films and other cultural displays. It underpins the many localised cross-cultural events occurring in our communities. It is ever present in our dialogue in the popular press. But still the question remains - what does it mean?

At the superficial level it means all of the above. It is part of that amorphous mass of actions, big and small, happening in our communities, which give tenancy to a desire to improve - or at least to discuss, interpret and define - the relationships between Indigenous and settler Australians.

At the political level reconciliation becomes mired in ideology, and this is where the Left-Right divide is most evident (although this should not be read as a political party based left-right divide). Here the discussion centres on what constitutes 'practical' reconciliation - as defined by the Prime Minister's focus on government programs of education, health and housing as opposed to the 'hard' issues of 'true' or 'substantive' reconciliation - that is, addressing disadvantage as well as the desire for constitutional change in a treaty, a bill of rights and just compensation for past acts of dispossession.

As a Federal government policy, it is possible that reconciliation is no more than an attempt to preserve the status quo, and indeed, given the abolition of the Aboriginal and Torres Strait Islander Commission, (ATSIC) in 2004, we may see a return to a more paternalistic 'whitefella' directed policy imposed on Indigenous Australia by the exigencies of 'mutual obligation' (SMH, 2004).

And what of the people's movement? The community surveys carried out by pollsters suggest that most people are in favour of reconciliation but are unsure of its meaning. Certainly there seems to be no desire for effective action on the 'hard' issues of reconciliation amongst the wider community.

Ten years after the inception of the Council for Aboriginal Reconciliation, when the national reconciliation documents were handed to Prime Minister Howard in May 2000, the nation had not yet agreed on a formal document for reconciliation. What was handed to the Prime Minister was a Declaration Towards reconciliation. There had been much discussion and dispute about the wording of the Australian Declaration For reconciliation. The words in dispute related to ownership of land and the inclusion of customary laws as well as the reference to an apology which the Prime Minister refused to make.

Many Indigenous and non-Indigenous leaders feel frustrated by the attitude of governments towards reconciliation.

Well-known activists within the reconciliation movement categorically state that the agenda for reconciliation was sidelined by the conservative Howard Government from 1996 to the present. "Howard stopped the bi-partisanship model... and withdrew from reconciliation. It [the government] showed a fundamental lack of understanding of the spiritual connections of Aboriginal lives... This is not an age of symbols and matters of the heart and spirit" (Glendenning, P., 2003, personal communication). Another notes, "In 1997 the government killed off any real actions toward reconciliation" (Glenn, 2003, personal communication).

In August 2002, the Senate initiated an inquiry into the "progress towards national reconciliation, including an examination of the adequacy and effectiveness of the Commonwealth Government's response to, and implementation of, the recommendations contained ... [in the Council's report]." (Parliament of Australia, 2002).

Many of the submissions into the inquiry commented on the lack of progress towards reconciliation since 2000 (ATSIC 2003; Centre for Public Law, UNSW, 2002; Cull, 2002; Edmund Rice Centre, 2002; National Assembly of the Uniting Church, 2002). The Federal government defended its response by noting that it is committed to 'practical' reconciliation rather than a rights based agenda.

In response to the Government's focus on 'practical' reconciliation the evidence from one discussion paper from the Centre for Aboriginal Economic Policy Research is that results of an assessment of Indigenous socio-economic status based on census data between 1996 and 2001 illustrates that their "relative wellbeing" overall has not kept pace with the rest of the population in a period of general prosperity. Indeed, according to Altman and Hunter, authors of the discussion paper, in " 'practical' socioeconomic terms there is less reconciliation in 2001 than in 1996" (2003, p.11).

In its submission to the Inquiry, Reconciliation Australia, the independent body which took over the work of the Council, expressed its concern about the redefinition of reconciliation, "narrowing it to the delivery of citizenship rights" (Reconciliation Australia, 2002, p. 2) and the lack of progress on many issues. It further notes to the Committee:

The Committee will be aware that a statement often heard is that "reconciliation is off the agenda". At the heart of this comment is a recognition that reconciliation resources are no longer visible and a belief that the current fed- 
eral government is not committed to the reconciliation process.

It is certainly true that the federal government has abrogated its leadership role in the broader reconciliation agenda and substituted a focus on practical reconciliation. This emphasis on practical reconciliation has limited the reconciliation process developed by the Council of Aboriginal Reconciliation. It is also true that sufficient resources are no longer available to allow wide community communication and education

Consequently, what Aboriginal people call the 'unfinished business' of reconciliation, those 'hard' issues of treaty, self determination and first nations rights, still remain at the crux of dispute of what constitutes reconciliation.

The following quote from an Indigenous person to the Senate Committee on the progress towards reconciliation clearly demonstrates that the frustrations and ambiguities of the reconciliation process still linger:

What is reconciliation? Nothing much has changed in Gove where I live reconciliation is a big white fella word. What does it mean? People ask me that and I don't know what to say. I was on Sydney Harbour Bridge when everybody walk across the bridge and they did that for 'reconciliation'. I been grown up in the bush and I know our law. Our law never changes...I don't understand your law. It always changes. The only thing that stays the same for the white man is that he never listens to our law and our kids keep getting locked up with that mandatory sentencing. I don't understand your reconciliation. (Commonwealth of Australia, 2003, p. 14)

The debates on meanings and perspectives of reconciliation must continue. The difficulty facing the reconciliation movement is that the political will for such an ongoing discourse is not forthcoming from the Federal leadership.

What is needed is a great commitment by the Federal government to the reconciliation process not only in terms of financial resources but also in terms of emotional and symbolic support for the movement. Until this occurs reconciliation will remain the 'unfinished business' of the Australian nation.

\section{References}

Aboriginal and Torres Strait Islander Commission (ATSIC) (1992). Twenty Five Years On: Parliamentary Speeches Marking the Anniversary of the Aboriginal Referendum of 27 May 1967.Commonwealth of Australia.

Aboriginal and Torres Strait Islander Commission (ATSIC) (2003). Submission to the Senate Legal and Constitutional References Committee Inquiry into the Progress Towards Reconciliation. Retrieved March 20, 2003 from http://www.aph.gov.au/Senate/committee/legcon_ctte/Reconciliation/index.htm

Akerman, P. (1996, June 30). Pauline Speaks for the Majority. Sunday Telegraph, p. 139

Altman, J.C. \& Hunter, B. H. (2003). Monitoring 'Practical' Reconciliation: Evidence from the Reconciliation Decade 1991 - 2001. Discussion paper no. 254. Canberra, ACT: Centre for Aboriginal Economic Policy Research.

Australian Reconciliation Convention (1997). Indigenous Peoples and the Constitution. Issues Papers. Australian Government Publishing Service.

Behrendt, L. (2001). Mind, Body and Spirit: Pathways Forward for Reconciliation. The Morpeth Lecture, University of Newcastle. Newcastle Law Review, 5 (1), 38-52.

Blainey, G. (1993) Drawing up the balance sheet of our history. Quadrant, July-August, 10-15.

Blainey, G. (1997, April). Black Future. The Bulletin, pp. 22-23.Borg, W. R. \& Gall, M. D. (1989). Educational Research: An Introduction (5th ed.). New York: Longman.

Brett, J. (2000). Why John Howard Can't Say Sorry. Arena Magazine, December 2000-January 2001, 35-41.

Brough, J. (1996, August14). Aborigines Face \$400m Budget Cut. Sydney Morning Herald, p. 1.

Brunton, R. (1998). Betraying the Victims. Institute of Public Affairs Backgrounder, February.

Brunton, R. (2000). Justice O'Loughlin and Bringing Them Home: A Challenge to the Faith. Quadrant, December, 37-42. Brunton, R. (2001) Cultural Wars. Institute of Public Affairs Review, March, 7-8.

Centre for Public Law (2002). Submission to the Senate Legal and Constitutional References Committee Inquiry into the Progress Towards Reconciliation. Retrieved March 7, 2003 from http://www.aph.gov.au/Senate/committee/legcon ctte/Reconciliation/index.htm

Chamberlin, P. (1993, June 7). Keating Appeals for Calm on Mabo. Sydney Morning Herald, p. 3.

Chamberlin, P. (1993, June 29). Reconciliation Separate from Mabo, Say Libs. Sydney Morning Herald, p. 3.

Chaney, F. (2002, June 3). Eddie Mabo Memorial Lecture, Melbourne. Retrieved May 6, 2003 from http://www.reconciliationaustralia.org/textonly/info/publications/speeches.html

Cockayne, J. (2001). More than Sorry: Constructing a Legal Architecture for Practical Reconciliation. Sydney Law Review, $23,577-596$.

Commonwealth of Australia (1991). House of Representatives. Parliamentary Debates. (Weekly Hansard no. 11) (June 5), pp. 4823-4854.

Commonwealth of Australia (1991). Aboriginal Reconciliation. An Historical Perspective. Chapter 6, Annual Report 1990 - 91. Department of Prime Minister and Cabinet. Australian Government Publishing Service. 
Commonwealth of Australia (1991). Council for Aboriginal Reconciliation: An Introduction. Canberra, ACT: Australian Government Publishing Service.

Council for Aboriginal Reconciliation (1992). Walking Together, 1. Australian Government Publishing Service.

Council for Aboriginal Reconciliation (1993). Exploring Common Ground. Available: http://www.austlii.edu.au/au/other/Indig.Res/car/pubs/html\#reports

Council for Aboriginal Reconciliation (1993). Making Things Right. Available: http://www.austlii.edu.au/au/other/Indig.Res/car/pubs/html\#reports

Council for Aboriginal Reconciliation (1994). Together We Can't Lose. Available: http://www.austlii.edu.au/au/other/Indig.Res/car/pubs/html\#reports

Council for Aboriginal Reconciliation (1994). Walking Together: The First Steps. Available: http://www.austlii.edu.au/au/other/Indig.Res/car/pubs/html\#reports

Council for Aboriginal Reconciliation (1994). Weaving the Threads. Available: http://www.austlii.edu.au/au/other/Indig.Res/car/pubs/html\#reports

Council for Aboriginal Reconciliation (1995). Going Forward - Social Justice for the First Australians.Available: htttp://www.austlii.edu.au/au/other/Indig.Res/car/pubs/html\#reports

Council for Aboriginal Reconciliation (1995). A Nation Working Towards Reconciliation. In Youth Studies Australia, 14 (4), 13-16.

Council for Aboriginal Reconciliation (1997). Improving Relationships; Valuing Cultures; Sharing History; Addressing Disadvantage; Responding to Custody Levels; Agreeing on a Document; Controlling Destinies. Key Issues Papers 1-8. Canberra: Australian Government Publishing Service.

Council for Aboriginal Reconciliation (1997). Proceedings from the Australian Reconciliation Convention, May 26-28, 1997. Books 1-5. Canberra, ACT: Commonwealth of Australia.

Council for Aboriginal Reconciliation (1997). The Path to Reconciliation Building a People's Movement. NSW Regional Meetings Summary, March 4-27.

Council for Aboriginal Reconciliation (1998). Towards Reconciliation. Activities for Reconciliation Week. Canberra: Australian Government Publishing Service.

Council for Aboriginal Reconciliation (2000). Walking the Talk: Commitments to Reconciliation. Proceedings from Corroboree 2000. Canberra: Pirie Printers.

Council for Aboriginal Reconciliation. Three Strategic Plan 1991-94. Available: http://www.austlii.edu.au/au/other/In$\operatorname{digLRes/car/1992/1/~}$

Council for Aboriginal Reconciliation. Three Strategic Plan 1995-98. Available: http://www.austlii.edu.au/au/other/In$\operatorname{digLRes/car/1995/1/strat.htm~}$

Council for Aboriginal Reconciliation. Three Strategic Plan (1998-2000). Available: http://www.austlii.edu.au/au/other/In$\operatorname{digLRes} / \mathrm{car} / 1998 / 5 /$

Council for Aboriginal Reconciliation (2000). Road Map for Reconciliation. Available: http://www.austlii.edu.au/au/other/IndigLRes/car/2000/10/index.htm

Council for Aboriginal Reconciliation (2000b). Reconciliation Australia's Challenge. Final Report of the Council for Aboriginal Reconciliation. Australian Government Publishing Service. ACT.

Council for Aboriginal Reconciliation (2001). Reconciliation Over to You. Walking Together, 30. Canberra: National Capital Printing.

Council for Aboriginal Reconciliation (no date). Australian Reconciliation Study Circle Kit. Canberra: Australian Government Publishing Service.

Council for Aboriginal Reconciliation (no date). The Path to Reconciliation - The People's Responses. Unpublished report.

Crough, G. (2002). A Practical Guide to Practical Reconciliation: What is the Reality of Indigenous Funding. Australian Universities Review, 45 (1).

Cull, K. (2002). Submission to the Inquiry on Progress Towards Reconciliation. Law Society of NSW. Retrieved March 5, 2003, from: http://www.aph.gov.au/Senate/committee/legcon_ctte/Reconciliation/index.htm

Deane, W. (1996). Signposts from Daguragu. Vincent Lingiari Lecture. Council for Aboriginal Reconciliation. Australian Government Publishing Service.

Deane, W. (1997) Speech delivered at the Australian Reconciliation Convention, May 26-28. Available: http://www.austlii.edu.au/au/other/IndigLRes/car/1997/3/Con\%20speeches.htm

Dodson, M. (1993). Aboriginal And Torres Strait Islander Social Justice Report 1993. Human Rights and Equal Opportunity Commission. Australian Government Publishing Service. ACT.

Dodson, M. (2000). Speech delivered at Corroborree 2000 Conference, Sydney, Australia, May 27. Available: www.austlii.edu.au

Dodson, P. (1996, May 22). Reconciliation at the Crossroads. Koori Mail, p. 12.

Dodson, P. (1997). Address to the National Press Club, November 28. Available: http://www.austlii.edu.au/au/other/IndigLRes/car/1997/2811.html

Dodson, P. (1999). Until these Chains are Broken. Fourth Vincent Lingiari Memorial Lecture. Available: http://www.austlii.edu.au/au/other/IndigLRes/car/pubs.html\#vincent

Edmund Rice Centre (2002). Submission to the Senate Legal and Constitutional References Committee Inquiry into the Progress Towards Reconciliation. Retrieved March 5, 2003 from http://www.aph.gov.au/Senate/committee/legcon_ctte/Reconciliation/index.htm 
Gaita, R. (2001, July). Why the Impatience, Genocide, 'Ideology' and Practical Reconciliation. La Trobe University Essay. Australian Book Review. National Book Council, Victoria.

Gale, P. (2001). Representations of Reconciliation. In M. Kalantzis \& W. Cope (Eds.), Reconciliation Multiculturalism Identities Difficult Dialogues, Sensible Solutions (pp. 123-133). Common Ground Publishing. Australia.

Gardiner-Garden, J. (1999). From Dispossession to Reconciliation. Parliamentary research paper 27, 1998-99. Parliamentary Library, Parliament of Australia. Available: http://www.aph.gov.au/library/pubs/rp/1998-99/99rpp27.htm

Glenn, H. (2003) Chief Executive, A Just Australia. Personal communication.

Glendenning, P. (2003) Edmund Rice Centre. Personal Communication

Gomersall, A. M., Davidson, G, \& Ho, R. (2000). Factors Affecting Acceptance of Aboriginal Reconciliation Amongst Non-Indigenous Australians. Australian Psychologist, 35 (2), 118-127.

Grattan, M. (Ed.). (2000). Reconciliation. Essays on Australian Reconciliation. Melbourne: Black Inc.

Hanna, M. (2000). Reconciliation in Olympism: Indigenous Culture in the Sydney Olympiad. Petersham, NSW: Walla Walla Press.

Hanson, P. (1996). Maiden speech to the House of Representatives, September 10. Available: http://www.onenation.com.au Hecate (2000). Reconciliation or Justice. Editorial, 26 (1), 4-9.

Hickson, M. (2000). After Corroboree. Arena Magazine, August, 14-19.

Hill, L. (1998). Pauline Hanson Free Speech and Reconciliation. Journal of Australian Studies, June, 10.

Howard, J. (1996). Robert Menzies Memorial Lecture. Available: http:/www.mrcltd.org.auuploaded_documents/ACFAD3.htm Howard, J.(2000, May 12). Towards a Common Destiny. Sydney Morning Herald, Features, p.

Howard, J. (2000b). Practical Reconciliation. In M. Grattan, Reconciliation: Essays on Reconciliation (pp. 89-96). Melbourne: Black Inc.

Howson, P. (1999). Rescued from the Rabbit Burrow. Quadrant, 43 (6), 10-14.

Howson, P. (2000). Reality and Fantasy, the Abject Failure of Aboriginal Policy. Quadrant, April, 44 (i4), 20-24.

Howson, P. (2002). Submission to the Senate Legal and Constitutional References Committee Inquiry into the Progress Towards Reconciliation. Retrieved March 5, 2003 from http:/www.aph.gov.au/Senate/committee/legcon_ctte/Reconciliation/index.htm

Huggins, J. (2002). Working the Walk: Activating Reconciliation. Armidale, NSW: University of New England.

Human Rights and Equal Opportunity Commission. (1997). Bringing Them Home Report. National Inquiry into the Separation of Aboriginal and Torres Strait Islander Children from their Families. Canberra: Australian Government Publishing Service.

Human Rights and Equal Opportunity Commission. Human Rights and Equal Opportunity Social Justice Commissioner Reports 1993 - 2001. Canberra: Australian Government Publishing Service.

Irving Saulwick \& Associates (2000). Research into Issues Related to a Document of Reconciliation. Council for Aboriginal Reconciliation, Reports no. 1 \& no. 2.

Irving Saulwick \& Associates (2000). Research into Issues Related to a Document of Reconciliation., Report no. 2. Indigenous Qualitative Research. Council for Aboriginal Reconciliation.

Johns, G. \& Brunton, R. (1999). Reconciliation What Does it Mean? Institute of Public Affairs Backgrounder, 11, (4).

Jull, P. (1999). Reconciliation and Renewal. Arena Magazine, 39, February, 20-24.

Keating, P. (1992). Redfern Park Speech. Reprinted in Indigenous Law Bulletin, August-September 2001, 5 (11).

Kelly, L. (1993). Reconciliation and the Implications for a Sovereign Aboriginal Nation. Aboriginal Law Bulletin, 3 (61), $10-13$.

Law Society of New South Wales (2002). Submission to the Senate Legal and Constitutional References Committee Inquiry into the Progress Towards Reconciliation. Retrieved March 6, 2003 from http://www.aph.gov.au/Senate/committee/legcon_ctte/Reconciliation/index.htm

Macintyre, S. \& Clark, A. (2003). The History Wars. Carlton, Victoria: Melbourne University Press.

Manne, R. (2001b). 'In Denial. The Stolen Generations and the Right', The Australian Quarterly Essay, Melbourne: Black Inc.

Manne, R. (2002, February, 23-24) The Colour of Prejudice. Sydney Morning Herald, Spectrum, pp. 4-6.

Manne, R. (Ed.). (2003). Whitewash: On Keith Windschuttle and the Fabrication of Aboriginal History. Melbourne: Black Inc.

McGeugh, P. (1997, October 18). Wik Without Worries. Sydney Morning Herald, p. 35

McKay, B. (Ed.). (1999). Unmasking Whiteness: Race Relations and Reconciliation. Nathan Campus: Queensland Studies Centre.

Moran, A.(1998). Aboriginal Reconciliation: Transformations in Settler Nationalism. Melbourne Journal of Politics, 25 (1), $101-132$.

Morgan, G. (2002). The Reconciliation Movement in Australia. Aboriginal Studies Association Journal, 1, 45-50.

Neill, R. (2002). White Out. Sydney: Allen \& Unwin.

Newspoll Market Research (2000). Indigenous Qualitative Research into Issues Relating to a Document of Reconciliation. Council for Aboriginal Reconciliation. Available: http://www.austlii.edu.au/au/other/IndigLRes/car/2000/5/indig.htm

Newspoll Market Research (2000). Quantitative Research into Issues Relating to a Document of Reconciliation. Council for Aboriginal Reconciliation. Available: http://www.austlii.edu.au/au/other/IndigLRes/car/2000/3/

Nicoll, F. (1998). Blacklash: Reconciliation after Wik. Meanjin, 57 (1), 167-183.

O’Donoghue, L. (1992). Twenty Five Years On: Parliamentary Speeches Marking the Anniversary of the Aboriginal Referendum of 27 May 1967. ATSIC: Commonwealth of Australia 
Parliament of Australia (2002). Terms of Reference. Inquiry into the Progress of Reconciliation. Available: http://www.aph.gov.au/Senate/committee

Partington, Geoffrey. (1998). Saying 'Sorry!' About Aboriginal Children: the Fundamental Problem. Australia and World Affairs, Winter, (37), 14-23.

Pratt, A., Elder, C., \& Ellis, C. (2000). Reconciliation: Origins, Policy, Practice, Representations, Meanings, Futures. Paper presented to the Diversity Conference - Imagining Ourselves: Reconciliation in the National Imagination. University of Technology Sydney, Australia, December 2000. Also in M. Kalantzis \& W. Cope (2001), Reconciliation Multiculturalism Identities Difficult Dialogues, Sensible Solutions (pp. 135-147). Common Ground Printing. Australia.

Read, P. \& Edwards, C. (Eds.). (1989). The Lost Children. Sydney: Doubleday.

Reconciliation Australia (2003). Submission to the Senate Legal and Constitutional References Committee Inquiry into the Progress Towards Reconciliation. Available: http://www.aph.gov.au/Senate/committee/legcon_ctte/Reconciliation/index.htm

Reynolds, H. (1981). The Other Side of the Frontier. Ringwood, Victoria: Penguin Books.

Reynolds, H. (1987). The Law of the Land. Ringwood, Victoria: Penguin Books.

Reynolds, H. (1998). This Whispering in Our Hearts. St Leonards: Allen \& Unwin.

Reynolds, H. (1999). Why Weren't We Told. Ringwood,Victoria: Viking (Penguin) Books.

Reynolds, H. (2001). An Indelible Stain, Ringwood,Victoria: Viking Books.

Ridgeway, A. (2001). Speech to United Nations Human Rights Commission in Geneva, Switzerland, March 26. Available : http://www.democrats.org.nsw

Rintoul, S. (2000, October 21). Beyond the Games, Nursing the Flame. The Australian, p. 10.

Ruddock, P. (2002). Commonwealth Government Submission to Senate Legal and Constitutional References Committee Inquiry into the Progress Towards National Reconciliation. Parliament of Australia. Available: http://www.aph.gov.au/Senate/committee/legcon_ctte/Reconciliation/index.htm

Summers, A. (2000, September 28). An Olympic Icon Signals Australia's Awakening. Sydney Morning Herald, p. 18.

Sweeney, B. \& Associates (1996). Unfinished Business: Australians and Reconciliation. Council for Aboriginal Reconciliation. Australian Government Publishing Service.

The Australian, (2000, December 8). Editorial. Bridge Across the Great Divide, p. 12.

Tully, J. (1997). A Fair and Just Relationship Between Aboriginal and Non Aboriginal Peoples. Paper delivered to the Institute for Humanities and Social Sciences, University of Sydney, Australia, September 1.

Windschuttle, K. (2002). The Fabrication of Aboriginal History. Paddington: Maclay Press.

Yunupingu, G. (Ed.). (1997). Our Land is Our Life. St Lucia: University of Queensland Press.

\section{About the Author}

\section{Dr Nina Burridge}

Nina Burridge began her career as a high school teacher in History and moved into higher education as a teacher educator. She sees herself as both an academic and an activists. Her main research interests have been Indigenous education and the implementation of the policy of reconciliation in the education and community sectors. She has published papers and educational materials on how Indigenous education in school and on approaches to reconciliation between Indigenous and non-Indigenous Australians in the current socio-political context. She has been the director of the Institute of Aboriginal Studies and Research at Macquarie University in Sydney and is currently lecturing in the Faculty of Education at the University of Technology, Sydney. Her emerging interests are in the areas of social justice and cultural diversity and she has been a campaigner for many issues related to refugee reforms and human rights at the local and national levels within the Australian community. 